\title{
The Obstacles in Fulfilling Social Protection for Indonesian Women Migrant Workers in Malaysia from 2016 to 2018
}

\author{
Ahmad Alfajri M.A \\ Department of International Relations, UIN Syarif Hidayatullah, Jakarta, Indonesia \\ alfajri@uinjkt.ac.id

\section{Halida Maulidia} \\ Department of International Relations, UIN Syarif Hidayatullah, Jakarta, Indonesia \\ halidamaulidia@gmail.com \\ Submitted: 21 November 2019; Revised: 10 March 2020; Accepted: 27 February 2020
}

\begin{abstract}
Abstrak
Berdasarkan data yang dikeluarkan oleh BNP2TKI, Malaysia adalah negara tujuan utama Perempuan Pekerja Migran Indonesia (IWMW) dan negara dengan tingkat pengaduan tertingi. Salah satu bentuk pengaduan IWMW adalah jaminan sosial. Peraturan jaminan sosial untuk IWMW juga dirasa masih sangat terbatas walaupun hal tersebut termasuk ke dalam hak pekerja migran. Di sisi lain, pemerintah Malaysia pun sudah mempunyai beberapa undang-undang mengenai perlindungan terhadap warga negara Malaysia dan non-warga negara Malaysia. Di dalam penelitian ini ditemukan 3 hambatan besar dalam pemenuhan jaminan sosial terhadap IWMW di Malaysia, yaitu hambatan hukum, tata kelola migrasi Indonesia, dan kebijakan imigrasi Malaysia. Di dalam tulisan ini ditemukan bahwa jaminan sosial di Malaysia tidak sepenuhnya mempertimbangkan pengalaman dan perspektif perempuan, dimana IWMW sangat kritis dalam isu ini. Lebih lanjut, pengaturan migrasi di kedua negara, Indonesia dan Malaysia, juga masih ditemukan banyak masalah. Ketiga faktor penghambat tersebut akan dianalisis menggunakan perspektif feminis security studies untuk melihat bagaimana keamanan yang adil secara gender.
\end{abstract}

Kata kunci: Jaminan sosial, perempuan pekerja migran Indonesia, hambatan hukum, peraturan migrasi Indonesia, kebijakan imigrasi Malaysia.

\begin{abstract}
According to BNP2TKI, Malaysia is the most popular destination country for Indonesian Women Migrant Workers (IWMW), as well as at the top list of IWMW complaints. One of those complaints is regarding the social protection issue. The provision of social protection for IWMW is still limited while it is part of migrant's rights. The Malaysian government has put some regulations that command its institutions to provide the protections both to its citizens and non-citizens. This study found three big constraints of procuring social protection to IWMW in Malaysia; they were legal barriers, problems in the regulation of Indonesia, and Malaysia immigration policy. In this article, the author analyzed those constraints using feminist theory. This article found that social protection in Malaysia has not fully considered women's perspectives and experiences while being critical. Furthermore, migration arrangements, both in Indonesia and Malaysia, are also problematic. Those three factors will be discussed in detail using a feminist perspective in looking at the whole problem and the relationship between the patriarchal system and the economy that suppress women.
\end{abstract}

Keywords: Social protection, Indonesian women migrant workers, legal barriers, regulation of Indonesia's migration, Malaysia immigration policy.

\section{INTRODUCTION}

For the past two decades, migrant workers have been one of the main contributors to economic growth in Southeast Asia. Two factors drive the migration phenomenon; they are gaps in the economics and social conditions and demographic differences in Southeast
Asian. Among other countries in the region, Indonesia ranked as the second-largest migrant worker country in Southeast Asia. Indonesian migrant workers usually work with low skill levels and generally are women (Raharto \& Noveria, 2012). 
Malaysia is the main destination country for Indonesian migrant workers in 2016-2018 (BNP2TKI, 2018). In 2017, the Malaysian government also announced that most foreign workers in Malaysia were Indonesian. Indonesian migrant workers, especially women, occupy mostly in Foreign Domestic Worker (FDM) sector (Jabatan Imigresen Malaysia). This FDM was 92,142 of the total 262,627 IWMW (Data Terbuka Malaysia, 2017). Indonesian Migrant workers become the main suppliers of human resources for the needs of economic development and industrialization in Malaysia, working in manufacturing sectors, service sectors, and domestic servants. Problems concerning on IWMW come mostly from domestic workers that generally experience discrimination at work and experience psychological violation, as well as become victims of economic and sexual exploitation (Ramdhany, 2016).

Social protection is not a new issue both for Indonesia and Malaysia. Indonesia has a regulation on social protection for migrant workers, as written in Law Constitution No. 18 of 2017 concerning the Protection of Migrant Workers (IOM, 2010). The law produces a derivative regulation, namely the Republic of Indonesia's Minister of Manpower Regulation No. 7 of 2017 concerning the Indonesian Workers 'Social Security Program, which includes the integration of migrant workers' social protection into the Managing Social Security Board of Employment, or called BPJS (Kementerian Ketenagakerjaan RI , 2017).

Malaysia also has several legal frameworks to regulate the provision of social protection for migrant workers. There are Federal Constitution of Malaysia, Employment Act, Workmen Compensation Act, Employees Provident Fund Act, Industrial Relations Act. However, in practice, these legal frameworks are not effectively implemented (Harkins, 2016). The ineffectiveness derives from the fact that some types of migrant workers do not belong within the legal framework.

Some problems in fulfilling social protection for IWMW also exist through the National Agency for Placement and Protection of Indonesian Workers (NAPPIW) data. The NAPPIW report shows that most complaints from Indonesian workers from 2016 to 2018 are coming from Malaysia. In 2016 there are 1,535 complaints. In 2017, there were 1,625 complaints, and in 2018, there were 2,877 complaints. The increase in the number of complaints from 2016 to 2018, especially during the placement period was significant according to the data collected after the revocation of the moratorium issued by the Government of Indonesia in 2011 against Malaysia (BNP2TKI, 2016). Therefore, the purpose of this article is to analyze the obstacles faced by Malaysia in the fulfillment of IWMW in social protection rights from 2016 to 2018.

\section{THEORETICAL FRAMEWORK}

This article used a feminist theoretical framework in looking at how the issue of social protection is important and why it is still difficult to provide for Indonesian women migrant workers in Malaysia. Furthermore, this article also discusses feminist security studies to help to observe the contested definition of security and how it relates to social protection for IWMW. Feminists' perspective will clearly describe the pressure toward women, which is caused by patriarchal systems.

\section{FEMINISM IN INTERNATIONAL RELATIONS}

Feminism argues that women have the same rights as men in the political, social, economic, and intellectual fields. Feminists pay attention to gender differences that show inequality for the interests and rights of women (Lerner, 1993). Feminist theory in International Relations (IR) seeks to raise a marginalized issue (gender) ignored in the study of IR. The portrayal of IR as a high politics implicitly makes gender undermined, and consequently, power exists without considering the role of women. IR, which was previously dominated by power and conflict-had experienced a shift when scientists who were influenced by the ideas of Marxism entered and presented a new problem, namely equality, and justice, which had been a marginal domain (Narain, 2014).

National security and national interests of a state are still very exclusive as the realm of men or what J. Ann Tickner calls as "hegemonic masculinity". This hegemony of masculinity is something difficult for women to reach. As a result, women only live in the domestic sphere, have secondary roles and professions in the social sphere. The gender bias that exists in the definition of security so far is 
trying to be redefined by feminist thinkers. Tickner defines security must pay attention that the existing gender hierarchy is the source of dominance and therefore becomes an obstacle in defining what security means. The definition is related to ideas about justice and emancipation as opposed to the existing order (Narain, 2014). Tickner emphasized that the understanding of IR, which claimed as neutral and objective, has made the hidden gender analysis. Feminists see the need for a dialectical process interpreted to listen and understand women's life experiences that are different from the meanings that have existed in the wider community. By looking at women's experiences, feminists try to see the gender hierarchy and aim to change that (Narain, 2014).

Feminists work using the ontology of social relations, and wherein there are social construction and analysis of variables. All of these things can be through a history of inequality in politics, economics, and social structure (Narain, 2014). Feminists pay more attention to the vulnerability of women in the country as an inseparable part of the relationship of gender hierarchies in international politics. For example, domestic violence is not a state concern, and most of these actions have no legal sanctions (Narain, 2014).

\section{FEMINIST SECURITY STUDIES}

Feminist Security Studies (FSS) by Laura Sjoberg tries to challenge the assumption that so far, security and gender issues are not relevant to each other. Feminist thinkers agree that gender is conceptually, empirically, and normatively appropriate for the study of international security. The definition of security so far refers to the level of resistance or protection from danger. Correspondingly, the feminism movement of the 19th and early 20th century exists because it wants to change the legal inequality against women, specifically their ability to choose and access to certain property, education, and work rights. It opposes the rejection of the distribution of damage by sex (Sjoberg, 2016).

The gender role that has been brought by thinkers in the concept of security in IR focuses on the security that the state "gives" to its citizens. FSS sees how state security depends on women as a biological and cultural reproduction of state identity. This statement develops in discussions about productive and reproductive work. In FSS, the relationship between personal and political is also the attention, seen from the relationship between the center of global politics and the marginalized, the relationship between economic politics, individual security and international security, and the relationship between gender, race, and class in security (Sjoberg, 2016).

\section{RESEARCH METHOD}

This study used a qualitative research method, included various approaches that did not depend on numerical measurements. The qualitative research tends to focus on one or several cases, conduct intensive interviews, or conduct an in-depth analysis of the history of a problem, become more attentive to the importance of an issue, and can conclude logically (King et.al., 1994). In collecting data, this research obtained primary data through interviews and secondary data through a literature study. In-depth interviews had several parties related to this research, such as UN Women Indonesia, ILO Indonesia, Serikat Buruh Migran Indonesia (SBMI), North-South Initiatives Malaysia, and two Indonesian women migrant workers who worked in the period 2016-2018.

This secondary data were from various research in the field. Some of them were Dr. Wouter van Ginneken's work entitled Social Protection for Migrant Workers: National and Internasional Policy Challenges (Ginneken, 2013), thesis entitled Negara dan Buruh Migran Perempuan: Kebijakan Perlindungan Buruh Migran Perempuan Indonesia Masa Pemerintahan Susilo Bambang Yudhoyono 2004-2010 (Azmy, 2012) and research works by Amorisa Wiratri Is Working an Empowerment Tool for Women? Case Study Indonesian Migrant Workers in Malaysia? (Wiratri, 2016). This article also collected some information from reports, such as ILO Social Protection for Migrant Workers in ASEAN: Development, Challenges, and Prospects (Oliver, 2018), Labour Migration from Indonesia: An Overview of Indonesian Migration to Selected Destinations in Asia and the Middle East (IOM, 2010), and Women Migrant Workers in the ASEAN Economic Community (UNWomen, 2017) 


\section{LITERATURE REVIEW}

Many articles have discussed the migrant workers' issues. This article will mention some of them. The first literature is a Journal article entitled Social Protection for Migrant Workers: National and Internasional Policy Challenges by Wouter van Ginneken (Ginneken, 2013). Ginneken explained the social security standards for migrant workers abandoned families. In his journal, he explained how the state at any economic level plays a role in providing social security for workers, provides an assessment of state policies in fulfilling social security for its people that have an impact on regional and international migration, and explains how the effects of the ratification of the International Labor Organization (ILO) and United Nations (UN) Conventions on Migrant Workers. According to Ginneken, high-income countries tend to be more open to employing temporary migrant workers than permanent workers because they do not require much attention from the government of the recipient country of foreign workers.

The difference between this research and the article of Ginneken is that IRs research focuses on fulfilling social security for Indonesian female migrant workers regardless of whether they are regular or irregular workers. This study also explains how Indonesia's efforts in meeting social security for workers to reduce the impact of the problems of Indonesian migrant workers in the destination country. Meanwhile, the article of Ginneken focused on irregular labor and how destination countries with high economic levels meet the social security aspects of workers. Also, this article does not see the influence of the ILO and the UN Convention on Migrant Workers for ratifying countries generally developed countries, whether they have been able to fulfill this convention or not.

The second literature is a thesis entitled Negara dan Buruh Migran Perempuan: Kebijakan Perlindungan Buruh Migran Perempuan Indonesia Masa Pemerintahan Susilo Bambang Yudhoyono 2004-2010 (Azmy, 2012). In this study, the author discussed the quality of protection policies for Indonesian migrant workers, especially women, during Susilo Bambang Yudhoyono's administration in 2004-2010. This research used a theory of representation and women's political participation by Joni Lovenduski and the theory of socialist feminism from Iris Young. TIRs research explains that the SBY government less noticed the participation of women migrant workers movement, and groups of migrant workers such as NGOs, Trade Unions, and Workers' Associations. To some extent, this research provides important information since it also discusses the policy of protection of Indonesian women migrant workers in Malaysia.

There are three differences between this article and the thesis. First, the thesis only explains the protection policy and not the social security aspects. Second, the period differences in the study. Ana's research specifically explains the SBY administration period 2004-2010, while the research was in the 2016-2018 period. Finally, the use of theory, although both used socialist feminist theory, Ana also added another theoretical perspective, namely Political Theory of Public Policy. Thus, the research results did not slightly describe the role of a community or government agency that influenced the process of public policymaking.

The last literature is an article entitled Is Working an Empowerment Tool for Women? Case Study Indonesian Migrant Workers in Malaysia? (Wiratri, 2016). This article explains the extent to which working as a domestic worker could empower Indonesian women through a feminist perspective.

Furthermore, this study found that working as a domestic worker did not fully lead to empowerment but also did not fully lead to exploitation. His study focused on the achievements obtained by women working abroad, not just accompanied by changes in cultural norms, especially concerning gender. This research uses a dialectical process method by listening to the experiences of women workers in Malaysia.

The article explained how feminism became a basic concept in explaining why women essentially do domestic work. In line with the points raised by feminism, this article explains whether work can empower women by looking at the experience of Indonesian domestic workers in Malaysia. Besides, this article also discusses the conditions of domestic workers ranging from the recruitment process to returning to Indonesia. There is a similarity in this article, which is both looking at the working conditions of Indonesian female domestic workers such as domestic workers, freedom for workers, working hours, and where 
they work. Moreover, this article analyzes the problem through the perspective of feminism.

The gap in this article and the author's article is in perspective. The article focuses on working as a tool to empower women, while this paper will look at fulfilling the aspects of social security for Indonesian Indonesian Migrant Workers. In this article, it is also sufficient to explain the process of women workers working from the recruitment process until they return to Indonesia, while this paper only looks at the process of IRle working in the destination country.

\section{RESULT AND ANALYSIS}

\section{SOCIAL PROTECTION FOR INDONESIAN WOMEN MIGRANT WORKERS IN MALAYSIA}

The United Nations states that everyone has the right to protection if he/she reaches old age, suffers from an illness, is unemployed, has a disability, and dies. The state must provide and implement social protection to its citizens. Thus the government is responsible for ensuring the implementation and participating in funding (Hutagalung \& Indrio, 2018). Malaysia already has several social protection schemes in the form of insurance for migrant workers. TIRs scheme, among others, regulates the social security provided for migrant workers, including Indonesian women migrant workers. Insurance for Indonesian women migrant workers in Malaysia are Foreign Workers Insurance Guarantee (FWIG), Foreign Workers Hospitalization \& Surgical Scheme (SPIKPA/ FWHS/ SKHPPA), Foreign Workers Compensation Scheme (FWCS), and Maid Insurance/Domestic Workers Insurance (Sarah, 2016).

Foreign Workers Insurance Guarantee (FWIG) is insurance required by the Immigration Department under Immigration Regulation No. 21 for foreign workers in various sectors, except domestic workers. This insurance is needed as a guarantee for foreign workers when they return to their home country. The period and premium for foreign workers to take part in this insurance depends on the country of origin of the foreign worker (Asia Pacific Migration Networks, 2012). Foreign Workers Hospitalization \& Surgical Scheme (SPIKPA/FWHS/SKHPPA). The Malaysian government, through this insurance, decide that every employer is obliged to provide health insurance for their foreign workers both for the agriculture sector and home workers. Foreign workers covered by this insurance can claim their insurance at a national hospital, and if the medical costs are more than RM 10,000, foreign workers must pay the rest by themselves (Kementerian Kesihatan Malaysia, 2011).

Foreign Workers Compensation Scheme (FWCS) is insurance that protects foreign workers from workplace accidents and repatriation costs from work during and outside of work time. This insurance is a form of implementing the Workmen's Compensation Act 1952 part 26 (2). All insurance costs will be borne by the employer, which includes risks of death, permanent disability, loss of salary due to temporary disability, medical care costs, and the return of foreign workers to the country of origin caused by death and permanent disability (Sarah, 2016). Domestic Workers Insurance is a social protection for domestic workers in Malaysia. This social insurance is available for domestic workers who experience accidental work accidents, work accidents that cause disability and medical care due to work accidents. Besides, this insurance scheme also provides costs for the repatriation of workers to countries of origin that are not covered by FWIG (Product Disclosure Sheet-Domestic Help Insurance ).

Some basic principles are needed to fulfill social security. These principles include equality of treatment. There is no discrimination between social security intended for local workers and foreign workers (Silva, 2002). Second, portability access to social security, the benefits will be paid even if the worker is in the country of origin or the country of employment - finally, the ease of administration. TIRs principle only happens if the two countries have mutual administrative assistance in filing, legal matters, and payment of benefits (Rivera, 1992).

The implementation of the provision of the four social security above with the existing social security principles follows these principles. First is health insurance; both citizens and non-citizens receive the benefits. However, the conditions for granting benefits are different for non-citizens. For this matter, non-citizens have different insurance schemes, namely SPIKPA or SKHPPA (Oliver, 2018). Next is the work accident benefit where Malaysia 
provides this benefit to citizens and non-citizens, but with a different scheme. TIRs difference is in the FWCS, which is given only to foreign workers, while SOCSO protects the local workers (Hamidi, 2016). Also, for domestic workers, since excluded from the Malaysian Workers Compensation Act, there are different schemes for domestic migrant workers, namely Domestic Workers Insurance (Product Disclosure Sheet-Domestic Help Insurance ).

Regarding the maternity benefits contained in the Employment Act 1955, it is the benefits of maternity leave (ASEAN, 2015). In practice, the provision of maternity benefits is not in line with the Employment Act 1955. TIRs are because before working in Malaysia, and foreign workers must carry out medical tests to prove that they are free from pregnancy, IRV, and tuberculosis.

Furthermore, the regulation also excludes domestic migrant workers. Therefore, if IWMW is pregnant, they are not permitted to work in Malaysia (Hamidi, 2016). The next principle is the portability of social security. Malaysia belongs to the exportability regime, where local workers get some guarantees that migrant workers do not get. TIRs are because migrant workers have access to medical care and work accidents, but family and pregnancy benefits that apply to local female workers are not available for migrants (UNWomen, 2017).

The final principle is the ease of administrative processes. The TIRs principle is in the form of reciprocal assistance in achieving, adjudication, and payment of benefits (Rivera, 1992). In seeing the fulfillment of this principle, it can refer to the existing insurance scheme. For IWMW in Malaysia, both Indonesia and Malaysia already have an insurance scheme but have not been fully implemented properly. There are 300 cases regarding insurance claims, 240 cases are termination of unilateral employment, 10 cases of death, 1 case of legal aid insurance claims, 33 sick insurance claims, and 9 insurance claims of termination of employment or unpaid salary for migrant domestic workers (DPN SBMI, 2018). In Malaysia, administrative-related problems arise because the majority of Indonesian workers are illegal or undocumented (Pereira, 2019).

The last problem faced by IWMW is when they want to obtain social security. IWMW tends to ignore their rights, employment contracts, issues related to documents, and conditions of work (Nurjanah, 2019). The first problem begins with knowledge or awareness of their rights. In the graph below, the percentage of IWMW knowledge of their rights in Johor Bahru, Malaysia. As many as $28.8 \%$ did not know their rights. Providing information about their rights has been done in the provisioning of work before departure. However, this process was not utilized seriously by the IWMW (Arisman \& Jaya, 2018).

\section{Knowledge of Rights ( $\mathrm{N}=165)$ (\%)}

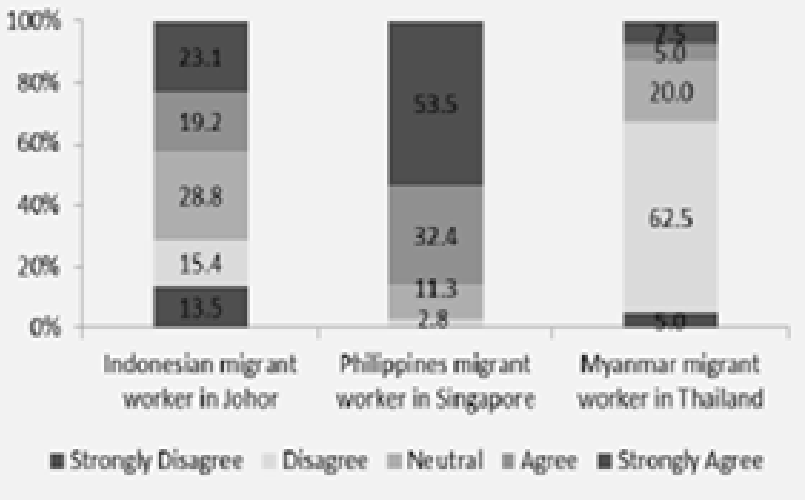

Figure 1. Knowledge of Rights (Arisman \& Jaya, 2018, p.77).

The problem regarding Indonesian women migrant worker's rights can be solved if they can join the work union because it is a good place for Indonesian women migrant workers to get information about their rights, social security and help them change their perspective on the right to social security. However, in Malaysia, there are only a few unions; in fact, it is rare for Indonesian women migrant workers to join a union (Nurjanah, 2019). It is because Indonesian women migrant workers in Malaysia mostly works in the household sector, where they do not belong in the Trade Union Act for association in Malaysia (Pereira, 2019). The next problem is the employment contract. In Malaysia, private labor agencies can regulate and handle the application of working migrant workers before being taken to the Immigration Department (Arisman \& Jaya, 2018). ILO Indonesia said that the majority of IWMW sent to work abroad had low education. Sometimes they cannot write and read. TIRs is 
unfortunate because it makes them uninformed about the employment contract (Harkrisnowo, 2019).

Another problem is the document. According to the Indonesian and Malaysian $\mathrm{MoU}$ in 2011 article 6, employers of Indonesian domestic workers in Malaysia can keep their passports for security reasons (Protokol Perubahan terhadap Nota Kesepahaman antara Pemerintah Republik Indonesia dan Pemerintah Malaysia mengenai Perekrutan dan Penempatan Pekerja Domestik Indonesia tahun 2011). By giving authority to the employer to keep IWMW's document, this places IWMW in a vulnerable position because they can lose their legal status if they run away from employers who commit acts of violence (IOM, 2010).

The last problem is the working conditions. They include working hours, workload, and holiday (Arisman \& Jaya, 2018). The standard working hours in Malaysia are 8 hours per day for all workers (Employment Act 1955, 2006), except for a housemaid. Domestic helpers in Malaysia work more than the stipulated time, while the average IWMW in Malaysia works for 14.82 hours per day. The working hour conditions create vulnerability for IWMW because they work inside the house, closed to the public, which sometimes invisible to their working conditions (Harkrisnowo, 2019). Apart from the domestic sector, problems regarding working hours and workload also come from the manufacturing sector. IWMW, who works in the manufacturing sector, often works more than 48 hours/week. Besides, manufacturing companies sometimes allow IWMW to work overtime and at night (night shift). This condition is a concern because no one can guarantee their safety. There is no supervision for them when they get home from work (Hamidi, 2016).

\section{Legal Framework}

Problem-related to legal issues are the exclusion of several categories of migrant workers from the Law on social security in Malaysia, the issue of the Memorandum of Understanding (MoU) of Indonesia and Malaysia regarding Recruitment and Placement of Domestic Workers in Indonesia, and the lack of law enforcement related to social security for IWMW in Malaysia.
The first obstacle comes from the exclusion of several categories of workers. The excluded categories include domestic workers, workers in the informal sector, and illegal or undocumented workers (Oliver, 2018). The excluded works are in the Employment Act, Workmen Compensation Act, Employees Provident Fund Act, and Trade Union Act (Oliver, 2018). The domestic helper does not belong to some parts of the Employment Act, such as minimum salary and working hours (Pereira, 2019).

The exclusion of domestic workers from several labor laws in Malaysia brings with it the problem that social security does not protect them, and there is no oversight at their place of work (Nurjanah, 2019). According to ILO Indonesia, the exclusion of the domestic sector from some social security law products is because there is no recognition as an employee in the informal sector.

Furthermore, ILO Indonesia also adds that domestic workers are helpers so that they do not include legal products related to social security. In fulfilling social security, IWMW Indonesia works a lot in the household sector, which is an informal job. It must be the focus because of their vulnerable working conditions and no legal products or mechanisms for them in Malaysia (Harkrisnowo, 2019).

Lastly is the status of undocumented workers. These workers are generally not registered for social security. However, they also cannot be avoided by work accidents or illness (Oliver, 2018). In line with this problem, Indonesia and Malaysia provide social security with conditions under which they must be legal workers.

"Most of the IWMW cases so far have been domestic workers who work illegally. About the number of undocumented IWMW cases, UN Women considers it important to think about the provision of social security for those without documents." (Nurjanah, 2019).

The next legal issue is a Memorandum of Understanding $(\mathrm{MoU})$ between Indonesia and Malaysia. The first problem is minimal protection. For example, in holding documents, minimum wages, and weekly rest (Protokol Perubahan terhadap Nota Kesepahaman antara Pemerintah Republik Indonesia dan Pemerintah Malaysia mengenai Perekrutan dan Penempatan Pekerja Domestik Indonesia tahun 2011). The other problems related to the $\mathrm{MoU}$ is not binding on the two countries, because the 
MoU does not have enforcement and supervision mechanisms. Finally, this MoU has not been renewed by Indonesia and Malaysia since it expired in 2016. This has resulted in the absence of bilateral agreements between the two countries, especially this $\mathrm{MoU}$, specifically for domestic workers, excluded from several laws in Malaysia. Other potential problems can arise if there are agency or recruitment agency agreements that make it difficult because there are no standards for regulating work agreements (Anwar, 2019).

The last legal problem is law enforcement (Pereira, 2019). It is important when there are employers and recruitment agents who do not provide social security to workers. With the existence of law enforcement, recruitment agents and employers can be sanctioned or punished (Nurjanah, 2019). This problem experienced by Castirah, who has obstacles to accessing social security from recruitment agencies and employers.

"I get health insurance only. Even then, only the photocopy of the card was given. My health insurance card is somewhere in the agent or at PT. At that time, I had a leg pain until it was swollen; I needed treatment. I asked the employer for money to be deducted from my salary for treatment, he said, he couldn't because my salary had been paid to the agent. When I asked the agent, they said tomorrow, but my insurance card was not given at all." (Castirah, 2019).

The obstacles in the law that IWMW faces, such as the exclusion of several categories in laws related to social security, problems in the $\mathrm{MoU}$, and minimal law enforcement, can be analyzed by including some understanding of feminist theory in international relations. Feminist contributions underline the importance of women's experience. Women's experience is less accommodated in some legal regulations for IWMW. Barriers in law experienced by IWMW in Malaysia are also no exception due to the existence of a gender hierarchy in Malaysia. This gender hierarchy is visible from the understanding that female migrant workers imported from countries with lower economic levels belong in the category of domestic workers (Kaur, 2013).

The obstacles in the law that IWMW faces, such as the exclusion of several categories in laws related to social security, problems in the $\mathrm{MoU}$, and minimal law enforcement, can be analyzed by including some understanding of feminist theory in international relations. Feminist contributions underline the importance of women's experience. Women's experience is less accommodated in some legal regulations for IWMW. Barriers in law experienced by IWMW in Malaysia are also no exception due to the existence of a gender hierarchy in Malaysia. This gender hierarchy is visible from the understanding that female migrant workers imported from countries with lower economic levels belong in the category of domestic workers (Kaur, 2013).

Besides, in the case of sexual reproduction needs for IWMW in Malaysia, there is no provision of social security instruments in the form of maternity benefits. In Malaysia, female migrant workers are not protected by the benefits of pregnancy because they have to undergo a medical check-up before working in Malaysia. If they are positive pregnant or have tuberculosis and IRV, they must go home (Hamidi, 2016). Although there is an insurance scheme in the form of Domestic Workers Insurance, however, this insurance does not accommodate the benefits of pregnancy for female domestic workers (Product Disclosure Sheet-Domestic Help Insurance).

\section{Regulation of Indonesia's Migration}

The issue of social security is closely related to migration governance (Nurjanah, 2019). Migration governance must encourage and urge the government to implement safe migration governance for Indonesian migrant workers (Migrant Care, 2018). Related to migration management, the government has a role in accompanying migrant workers during the migration process. Regarding migrant workers, IWMW is no exception. Assistance must have three stages, namely pre-placement, placement period, and post-placement (Lastati, 2019). In the pre-placement period, the government must provide safe and correct migration procedures, so that migrant workers avoid illegal or non-procedural pathways. During the placement period, the government must be able to guarantee the fulfillment of rights and protect migrant workers as a whole if problems occur in the placement country. Finally, in the post-placement period, migrant workers deserve to get 
assistance so they can develop the area where they come from and so that they do not return to work as migrant workers (Nurjanah, 2019).

Regarding social security for IWMW in Malaysia, it can focus on migration management in the pre-placement and placement period. The first migration governance is pre-placement. At this stage, there must be a correct and safe migration procedure. The first stage of this period begins with the provision of information for working abroad. However, data from interviews conducted with UN Women Indonesia shows that information regarding working abroad was not enough. There are still many prospective workers who are confused about how to work (Nurjanah, 2019). Sofi, IWMW, who works in the Malaysian manufacturing industry, experienced incorrect information given at the beginning of the migration period.

"Initially, from school, there was the distribution of labor abroad. Then the people who want to work abroad are recruited. I was recruited to work in Malaysia. Initially, my school offered schools while working in Malaysia. For work, yes, but not for school. So it is not following with what was originally said." (Gayuh, 2019).

assistance so they can develop the area where they come from and so that they do not return to work as migrant workers (Nurjanah, 2019).

Regarding the pre-placement period, North-South Initiatives Malaysia sees IWMW's social security issues as being closely related to the recruitment process and the lack of provided-training. Castirah is an example. She works through procedural channels, with a passport and entering through an agent. She experienced work problems because agents exploited her.

"I got job training before leaving. But when I had a problem like that time I was sick, I didn't know where I should use my insurance. That's because my work conditions are closed. I can't leave the house before, so I don't know anything. The big problem, I ran away because I was not paid with my agent. My salary is held with the allegation so that the money is not sent to the village so that it does not run out, so it is held by the agent. After that, the agent also arranged a rule not to hold a cellphone. If I want to communicate with my family, I had to the agency only once every 3 months, and only 5 minutes of telephone time is given." (Castirah, 2019).
The next migration governance is during the placement period. There must be bilateral cooperation between the two countries, Indonesia and Malaysia. Social security created by the Indonesian government cannot run without inter-state cooperation because Indonesian law is different from another country. Therefore, it is important to make bilateral cooperation, especially for IWMW's social security issues.

"Barrier to IWMW's social security in Malaysia is BPJS only applies in Indonesia following Law No. 18 of 2017. So for the BPJS, it can apply abroad; there must be another legal rule. So this social security can apply to migrant workers and can apply abroad. Special schemes for providing social security for migrant workers do not yet exist and should exist." (Anwar, 2019).

What feminists security studies (FSS) are individual security as a new form of security definition. FSS draws attention that the gender role that has been brought by thinkers in the concept of security in IR focuses on the security that the state "gives" to its citizens (Sjoberg, 2016). The definition of security, which is still state-centric, has made security at the individual level experiencing many obstacles to consider in the IR field. Security as a safe place to work and get out of structural violence is a new definition that feminists want to lift (Narain, 2014). Feminist thinkers agree that gender is conceptually, empirically, and normatively appropriate for the study of international security. The definition of security so far refers to the level of resistance or protection from danger, seen from the relationship between the center of global politics and the marginalized, the relationship between economic politics, individual security and international security, and the relationship between gender, race, and class in security (Sjoberg, 2016).

About the barriers to fulfilling social security, the migration management that Indonesia provides for IWMW is still not enough to guarantee the safety of its workers. The socialization of safe migrant work has not been well, as indicated by the lack of guaranteeing security at the individual level; in this case, female migrant workers (Nurjanah, 2019). 


\section{Malaysia Immigration Policy}

The last obstacle to IWMW's social security provision was the Malaysian immigration policy. Previously, we need to look at the four phases in managing migration in Malaysia. This governance has immigration policies since 1970. In the first phase, Malaysia opened the door for the entry of migrant workers in 1970-1980, where the government applied a tolerant policy towards the recruitment of foreign workers. In the second phase, 1981-88, the Malaysian government legalized the recruitment of foreign workers and signed bilateral agreements with worker's origin countries. In the third phase of 1989-1996, Malaysia began a regulatory program to restrict the arrival of foreign workers. The fourth phase began in 1997. Migration policy in this phase is a result of the 1997-1998 financial and economic crisis aimed at controlling illegal migration (Kaur, 2008).

In the last phase, there are several steps to apply. These steps include the signing of an $\mathrm{MoU}$ or memorandum of understanding with the sending country of migrant workers. The signing of this $\mathrm{MoU}$ has an intention to regulate migrant workers who are less skilled. The third is the introduction of a new law that formalizes diverse recruitment policies. This policy is to reduce dependence on one particular racial group. This policy also makes the government designate certain sectors for certain racial groups (Kaur, 2008).

Table 1. Recruitment of Migrant Workers by Country of Origin and Sector.

\begin{tabular}{|l|l|}
\hline SECTOR & COUNTRY \\
\hline Construction & $\begin{array}{l}\text { Philippines (male), Indonesia, Cambodia, Kazakhstan, Laos, Myanmar, } \\
\text { Nepal, Thailand, Turkmenistan, Uzbekistan and Vietnam, Bangladesh }\end{array}$ \\
\hline Manufacturing & $\begin{array}{l}\text { Philippines (male), Indonesia (female), Cambodia, Kazakhstan, Laos, } \\
\text { Myanmar, Nepal, Thailand, Turkmenistan, Uzbekistan and Vietnam, } \\
\text { Bangladesh }\end{array}$ \\
\hline $\begin{array}{l}\text { Plantation/ } \\
\text { Agriculture }\end{array}$ & $\begin{array}{l}\text { Philippines (male), Indonesia, India, Cambodia, Kazakkstan, Laos, } \\
\text { Myanmar, Nepal, Thailand, Turkmenistan, Uzbekistan and Vietnam, } \\
\text { Bangladesh }\end{array}$ \\
\hline Service & \\
\hline - Restaurant & $\begin{array}{l}\text { All source countries for general worker posts (except India - cooks } \\
\text { only). Restaurants in major towns in Peninsular Malaysia }\end{array}$ \\
\hline - Laundry & All source countries except India \\
\hline -Cleaning Sanitation & All source countries except India \\
\hline - Caddy & All source countries except India \\
\hline - Resort Islands & All source countries except India \\
\hline - Welfare Homes & All source countries excepf India \\
\hline -Cargo & All source countries except India \\
\hline - High Tension Cable & India only \\
\hline Domestic Workers & Sri Lanka, Indonesia, Thailand, Philippines and Cambodia \\
\hline Foreign Nurses & $\begin{array}{l}\text { Albania, India, Bangladesh, Philippines, Pakistan, Indonesia and } \\
\text { Myanmar }\end{array}$ \\
\hline
\end{tabular}

Note. Data is collected from Malaysian Immigration Department.
The table above shows the latest policy of the Malaysian government to produce a grouping of workers based on race or country of origin. This policy indirectly directs female workers to certain employment sectors, which also lead to the feminization of migrant workers in Malaysia. Male migrant workers occupy the construction, agriculture and services sectors while female migrant workers occupy the manufacturing, sector services such as cleaning and hospitality sector as well as domestic services (Kaur, 2015). Furthermore, this policy also addresses the migration relationship of certain female workers between Indonesia and Malaysia, where IWMW in Malaysia has a specific group for the domestic and manufacturing sectors (Hamidi, 2016).

Starting with the participation of women in Malaysia to work in the formal sector, impacting the vacant employment in the domestic and nurse sectors, prompting Malaysia to issue a policy to accommodate the domestic sector and nurses from women workers in neighboring countries. (Kaur, 2013). Ethnicity is one of the reasons migrant workers belong to the domestic realm. Only a few migrant workers from certain countries can become domestic workers in Malaysia. Such as IWMW, where they become domestic migrant workers because of cultural, ethnic, and religious similarities with Malays. This condition is in line with what socialist feminists assume regarding social pressure on women, namely the integration of capitalist and patriarchal systems that suppress women who are influenced by factors of race, social class, gender, and nation (Kaur, 2013).

This employment policy has led to unprecedented employment opportunities for semi-skilled and unskilled women workers and has consolidated the emergence of certain women's migration relations between Indonesia and Malaysia (Hamidi, 2016). By this, the grouping of certain jobs based on the country of origin of migrant workers leads to a capitalist and patriarchal system that works together to suppress women or Interactive-system explanation of Women's oppression by Iris Marion Young (Tong, 2009). The interactive system of IWMW in Malaysia can be illustrated by the "sexual division of labor," which results in "Gender bias in capitalism," namely the marginalization of women which produces women as the 
second and most important workforce in the capitalist system (Tong, 2009).

The analysis of the sex division of labor takes into account the characteristics of the individuals who carry out production activities and who performs reproduction in society. This analysis looks at who gives orders, who does the work, who works long and who gets less, who receives relatively high wages and relatively low wages (Tong, 2009).

The capitalist system can be seen from Malaysia's awareness as a middle-upper income country in Asia to get out of the "middle-income trap." This system then pushed Malaysia to make policies following the need for cheap labor. Malaysia sees women migrant workers, especially domestic helpers, as having an important role in the social reproduction needs of their middle-class citizens(Elias, 2013). These needs seemed to be the answer to the economic problems in Indonesia because sending workers abroad can be a mechanism to reduce the negative effects of high unemployment, especially in rural areas (Elias, 2013).

However, the progress of economic growth in Malaysia does not match the country's protection of migrant workers, including IWMW. Mr. Adrian from the North-South Initiatives saw that in Malaysia, there was aggressive economic growth.

"I think Malaysia develops very fast middle-income GDP

because of exploiting migrant workers. We cannot continue to deny social protection just because we need profit because we want to develop faster. Because when you have aggressive development. So you make more pressure on the migrant workers, you make them work overtime with no holidays. So this is just the result of the development aggressive." (Pereira, 2019).

Mr. Adrian revealed that many migrant workers, especially IWMW, did not know their rights because Malaysia is eager for its GDP to grow rapidly (Pereira, 2019). From a socialist feminist perspective as the desire of capitalism, it directly or indirectly will shape who is a worker in the main employment sector or as a secondary worker. Besides, the concept of individual security -which in this case has not been taken seriously by Malaysia- is seen by a feminist perspective as the reason why Malaysia's immigration policy depends on the concept of national interest in the pursuit of economic growth (Elias, 2013).

\section{CONCLUSION}

With a social background and the development of different countries, Indonesian workers see opportunities to work in Malaysia better than in Indonesia. The migration of migrant workers is a new pattern of relations between Indonesia and Malaysia. However, the sending of migrant workers has caused several social problems, one of which is social security. Social security is the protection provided by the state to its citizens regarding basic living needs that cannot be provided by them, such as health and pensions. This social security has the principle of non-discrimination, portability, and ease of administrative access.

In Malaysia, social security for migrant workers has several insurance schemes. The first scheme is the Foreign Workers Insurance Guarantee (FWIG), Foreign Workers Hospitalization \& Surgical Scheme (FWHS), Foreign Workers Compensation Scheme (FWCS), and Maid Insurance / Domestic Workers Insurance. However, IWMW faces many problems in obtaining social security. The problem is ignorance of their rights, work contracts, paperwork, and conditions of work. These problems are the result of obstacles in the legal framework, governance of Indonesian migration, and Malaysian immigration policy.

Legal barriers consist of exemptions from the category of workers in the Malaysian Manpower Act, MoU issues, and the lack of law enforcement. Furthermore, regarding the governance of Indonesian migration, namely providing information and job training that has not been adequately maximum. Finally, Malaysia's immigration policy groups female migrant workers into certain groups of workers so that they do not involve in several social security products.

Feminist contributions in the methodology of international relations analyze legal barriers by including the experience of alienated women in the international world. Regarding the governance of Indonesian migration, feminists see the state as not yet concerned with individual security.

Furthermore, Malaysian immigration policies that group migrant workers into certain categories. Malaysia's immigration policy uses the concept of feminist foreign policy and socialist feminist analysis, which sees a capitalist and patriarchal system that blends to suppress women. 


\section{REFERENCE}

Anwar, B. (2019, May 2). Jaminan Sosial untuk Perempuan Pekerja Migran Indonesia di Malaysia, periode 2016-2018. (H. Maulidia, Interviewer)

Arisman, \& Jaya, R. K. (2018). Protection of Human Rights and Labour Migration for Employment Purposed across ASEAN. Jakarta: CSEAS

ASEAN. (2015). Social Security and Maternity Protection for Female Workers: Laws and Practices in ASEAN. Retrieved from https://www.asean.org/wp-content/uploads/images /2015/August/ASEAN-Labour-Ministerial-Meeting-docu ment/maternity\%2012_3_2014.pdf

Asia Pacific Migration Networks. (2012). MSIG Insurance. Retrieved from http://apmigration.ilo.org/resources/mou-between -government-of-the-republic-of-indonesia-and-the-govern ment-of-malaysia-on-the-recruitment-and-placement-of-in donesian-dom

Asia Pacific Migration Networks. (n.d.). Protokol Perubahan terhadap Nota Kesepahaman antara Pemerintah Republik Indonesia dan Pemerintah Malaysia mengenai Perekrutan dan Penempatan Pekerja Domestik Indonesia tahun 2011. Retrieved from http://apmigration.ilo.org/resources/mou-be tween-g

Azmy, A. S. (2012). Negara dan Buruh Migran Perempuan: Kebijakan Perlindungan Buruh Migran Perempuan Indonesia Masa Pemerintahan Susilo bambang Yudhoyono 2004-2010. Yayasan Pustaka Obor Indonesia.

BNP2TKI. (2016). Data Penempatan dan Perlindungan Tenaga Kerja Indonesia tahun 2016. Retrieved from http://portal .bnp2tki.go.id/read/12024/Data-Penempatan-dan-Perlind ungan-TKI-Periode-Tahun-2016.html.

BNP2TKI. (2018). Data Penempatan dan Perlindungan PMI periode bulan September 2018. Retrieved from http://portal .bnp2tki.go.id/read/14133/Data-Penempatan-dan-Perlind ungan-TKI-Periode-Tahun-2018.html.

Castirah. (2019, May 15). Jaminan Sosial untuk Perempuan Pekerja Migran Indonesia (PPMI) di Malaysia, periode 2016-2018. (H. Maulidia, Interviewer)

CHUBB. (2018). Product Disclosure Sheet-Domestic Help Insurance. Retrieved from https://www.chubb.com/my-en/_assets/doc uments/domestic-help_eng.pdf

Data Terbuka Malaysia. (2017). Jumlah Pekerja Asing PLKS Aktif Mengikuti Jantina dan Negara Sumber. Retrieved from http://www.data.gov.my/data/ms_MY/dataset/jumlah-peker ja-asing-plks-aktif-mengikut-jantina-dan-negara-sumber

DPN SBMI. (2018). SBMI Tangani 1500 Kasus BMI Periode 2015 2017. Retrieved from http://sbmi.or.id/2018/12/sbmi-tan gani-1500-kasus-bmi-periode-2015-2017/

Elias, J. (2013). Foreign Policy and The Domestic Worker: The Malaysia-Indonesia Domestic Worker Dispute. International Feminist Journal of Politic, 15(3). doi:10.1080/14616742.2012.755835

Employment Act 1955. (2006). Employment Act 1955. Retrieved from https://www.ilo.org/dyn/travail/docs/1496/Employ ment\%20Act\%201955.pdf

Gayuh, S. (2019, May 15). Jaminan Sosial untuk Perempuan Pekerja Migran Indonesia (PPMI) di Malaysia, periode 2016-2018. (H. Maulidia, Interviewer)
Ginneken, W. V. (2013). Social Protection for Migrant Workers: National and International Policy Challanges. European Journal of Social Security, 15(2), 210. doi:10.1177/138826271301500206

Hamidi, M. (2016). Indonesian Female Factory Workers: The Gendered Migration Policy in Malaysia. People: International Journal of Social Science.

Harkins, B. (2016). Review of Labour Migration Policy in Malaysia. Bangkok: ILO.

Harkrisnowo, S. (2019, April 5). Jaminan Sosial untuk Perempuan Pekerja Migran Indonesia (PPMI) di Malaysia, periode 2016-2018. (H. Maulidia, Interviewer)

Hutagalung, S. A., \& Indrio, V. T. (2018). Laporan Tematik Studi Midline Tema 3: Akses Perempuan Buruh Migran Luar Negeri terhadap Layanan Perlindungan. Smeru Research Institute.

IOM. (2010). Labour Migration from Indonesia: An Overview of Indonesian Migration to Selected Destinations in Asia and The Middle East. Jakarta: International Organitation for Migration.

Jabatan Imigresen Malaysia. (n.d.). Retrieved from http://www.imi .gov.my/index.php/ms/pembantu-rumah-asing.html\#

Kaur, A. (2008). International Migration and Governance in Malaysia: Policy and Performance. UNEAC Asia Papers, 22, 4-18.

Kaur, A. (2013). Asia, Gender and Migration. In I. Ness (Ed.), The Encyclopedia of Global Human Migration. doi:10.1002/9781444351071.wbeghm042

Kaur, A. (2015). Migration and Integration in Europe, Southeast Asia, and Australia. Amsterdam: Amsterdam University Press.

Kementerian Kesihatan Malaysia. (2011). Kaedah Pelaksanaan Skim Perlindungan Insurans Kesihatan Pekerja Asing. Retrieved from http://www.moh.gov.my/index.php/pages/view/369.

Kementerian Ketenagakerjaan RI. (2017). Peraturan Menteri Ketenagakerjaan RI No. 7 tahun 2017 tentang Program Jaminan Sosial Tenaga Kerja Indonesia. Retrieved from https://jdih.kemnaker.go.id/data_puu/KEP MENAKER\%20NO\%20206\%20TAHUN\%202017.pdf

King, G., Keohane, R., \& Verba, S. (1994). Designing Social Inquiry: Scientific Inference in Qualitative Research. New Jersey: Princeton University Press

Lastati, D. (2019, 29 April). Migrasi Buruh Migran. Pusat Sumber Daya Buruh Migran. Retrieved from https://buruhmi gran.or.id/2019/04/29/migrasi-buruh-migran/

Lerner, G. (1993). The Creation of Feminist consciusness. From The Middle Ages to Eighteen-Seventy. New York: Oxford University Press.

Migrant Care. (2018). Perwujudan Tata Kelola Migrasi Aman (safe Migration). Retrieved from Migrant Care: http://www.mi grantcare.net/program/perwujudan-tata-kelola-migra si-aman-safe-migration/

Narain, S. (2014). Gender in International Relations: Feminist Perspectives of J. Ann Tickner. Indian Journal of Gender Studies, 21(2). doi:10.1177/0971521514525085

Nurjanah, N. (2019, Maret 28). Jaminan Sosial Perempuan Pekerja Migran Indonesia (PPMI) di Malaysia, periode 2016-2018. (H. Maulidia, Interviewer)

Oakton Community College. (2012). A Very Short Summary of 
Socialist Feminist Theory and Practice Socialist Feminist. Retrieved from https://www.oakton.edu/user/4/ghamill/So cialist_Feminism.pdf

Oliver, M. (2018). Social Protection for Migrant Workers in ASEAN: Development, Challanges, and Prospects. Thailand: ILO.

Pereira, M. A. (2019, Mei 3). Jaminan Sosial untuk Perempuan Pekerja Migran Indonesia di Malaysia, periode 2016-2018. (H. Maulidia, Interviewer)

Raharto, A., \& Noveria, M. (2012). Advocacy Group for Indonesian Women Migrant Workers. Jurnal Kependudukan Indonesia, VII(1).

Ramdhany, D. R. (2016). Responsibility of Protection Indonesian Female Migrant Workers. International Journal of Business, Economics and Law, 10(4).

Rivera, M. M. (1992). Social Security Protection of Migrant Workers. Asian and Pacific Migration Journal, 1(3-4). doi:10.1177/011719689200100305

Sarah, N. (2016, June 28). Mengenal Asuransi bagi Buruh Migran di Malaysia. Pusat Sumber Daya Buruh Migran. Retrieved from https://buruhmigran.or.id/2016/06/28/mengenal-asur ansi-bagi-buruh-migran-di-malaysia/

Silva, M. H. (2002). Standards fot the XXIst Century: Social Security. Austria: ILO.

Sjoberg, L. (2016). What, and Where, is Feminist Security Studies? Journal of Regional Security, 143-161.

Tong, R. (2009). Feminist Thought. Colorado: Westview Press.

UNWomen. (2017). Women Migrant Workers in the ASEAN Economic Community. Thailand: UN Women Asia Pacific.

Wiratri, A. (2016). Is Working an Empowerment Tool for Women? Case Study Indonesian Migrant Workers in Malaysia. Journal Masyarakat Indonesia, 39(1). doi:10.14203/jmi.v39i1.292 